\title{
Translating Self-Translation and the Units of the Translation: the Case of Nabokov
}

\author{
ZSUZSA HETÉNYI \\ ELTE BTK Orosz Nyelvi és Irodalmi Tanszék, H-1088 Budapest, Múzeum krt. 4/D. \\ Department of Russian Language and Literature, Faculty of Humanities, Eötvös Loránd University \\ E-mail: hetenyi.zsuzsa@btk.elte.hu
}

(Received: 23 November 2017; accepted: 17 January 2018)

\begin{abstract}
From the point of view of translation studies, Nabokov's case, his practicing selftranslation is very apt to shed light on some new aspects of practical and theoretical problems of literary translation. As several of his novels were self-translated, the two original versions represent a double authenticity. Translating Nabokov into a third language raises a number of practical problems. The paper also challenges the notion of the minimal and the maximal unity as well as the axiomatic question of equivalence.
\end{abstract}

Keywords: Nabokov, self-translation, units of translation, bilingual authors, hybrid text, intertextuality

Language as such was an adventure for Nabokov from the very beginning, from his trilingual childhood. Translation into Russian from English and French was his favourite challenge besides writing poetry during his early years of emigration but the conscious change of language of writing was marked by the abrupt caesura of moving to the USA in 1940 . However, this change was prepared in a way by his earlier self-translations already in 1936, after the shock of discovering a superfluous translation of his Russian Камера обскура by Winnifred Roy, replaced by his own version in 1938 - a new English text, a completely reworked new novel that only followed the English self-translation of Despair in 1937. Another important change was connected to his translating activity, namely, the switch from writing uniquely poetry to the prose, first to the short stories, the most prolific period of which coincides with his Berlin years, and very quickly to the novels that finally earned him the rank of a bestseller writer and one of those authors who defined 20th-century prose and prepared its end-of-century postmodern turn. Both Romain Rolland's Николка Персик (translated in 1921 and published in 1922) and Аня в стране чудес (translated in 1922 and published in 1923) became subjects of clear localization (domestication) in his hands, and both required extremely high creative invention. Not only Lewis Carroll's sophisticated and multilevel wordplays, first of all, the portmanteau method (this fusion of two or more words in Nabokov's texts I call metamorphusion ${ }^{1}$ ) influenced his prose style forever but, as

\footnotetext{
${ }^{1}$ Nabokov makes even more of these plays than Carroll: for example, Mock Turtle becomes Yenynaxa, a fusion of yenyxa 'nonsense, humbug' and череnaxa 'turtle'.
} 
I argue elsewhere, also the British writer's special worldview on different worlds, secrets, and coded language of symbols and philosophy (HETÉNYI 2018).

With his emigration, the direction of his translations had been changed, and besides his self-translations of his Russian novels and after some significant translations of Russian classics, ${ }^{2}$ he achieved the major four-volume 2000-page Eugene Onegin (1964) with commentaries where he (a master of form) did not respect the characteristic Onegin-strophe and eliminated the rhymes completely but explained all tiny details from the way of life of Russian nobles and Russian prosody to the manuscript versions, etymology, and the differences between Russian, French, and English culture. Thus, the question of these completely different translation strategies is inevitable: how the localizing and domesticating young Nabokov turned in his mature years into a fanatic of philology, a "literalist" translator? I think that the clue of the answer is the direction of the translation, that is, the aligning to the dominance of Russian culture over the English or French one. The polyglot Nabokov's early translations were made for Russian children and aimed to sound and to be read as real Russian texts, a Russian fairy tale by Carroll and a Russian folklore narrator of Rolland. In his late English Onegin, Nabokov wished to explain all details and beauties of his Pushkin and his lost love, the Russian language and culture to the English reader. He was all his life committed to this Russian orientation that is why he also became a self-translator - in order to initiate the English reader into his Russian novels and short stories written before Lolita, and let the English reader know from where Lolita originated. Russian was Nabokov's only native language.

The same dominance is unravelled from his only two self-translations into Russian, Другие берега (1954) and Лолита (1967). From the complicated transformation how Nabokov's memoirs in English entitled Conclusive Evidence (1951) (including a chapter on Mademoiselle O, written originally in French) were transformed through Другие берега into the second edition of Speak, Memory! (1967), I wish to underline a remark of the author from the foreword to this last one, allowing to understand that memory works more deeply and more accurately in his native Russian: "I revised many passages and tried to do something about the amnesic defects of the original [...]. I have not only introduced basic changes and copious additions into the initial English text, but have availed myself of the corrections I made while turning it into Russian. This re-Englishing of a Russian re-version of what had been an English re-telling of Russian memories in the first place, proved to be a diabolical task..." (NABOKOV 2000: XI-XII). It is to the reader to discover that the descriptions in the Russian version are more emotional, even sensual. Nabokov's synesthetic capacities, for example, are illustrated in a longer paragraph with rich metaphors from all five senses, ${ }^{3}$ while in English, we can read only "the

\footnotetext{
${ }^{2}$ A volume of Pushkin, Lermontov, and Tyutchev's poems, Lermontov's A Hero of Our Time (with his son Dmitry) and The Song on Igor's Campaign.

3 “'Не знаю, впрочем, правильно ли тут говорить о 'слухе': цветное ощущение создается по-моему осязательным, губным, чуть ли не вкусовым чутьем. Чтобы основательно определить окраску буквы, я должен букву просмаковать, дать ей набухнуть или излучиться во рту, пока воображаю ее зрительный узор. Чрезвычайно сложный вопрос, как и почему малейшее несо- 
color sensation seems to be produced by the very act of my orally forming a given letter while I imagine its outline" (NABOKOV 2000: 17).

Nabokov undertook the only novel's self-translation into Russian (Lolita) because of the fear to see it in other translators' hands. 1967 marks a year when the English memoir is completed and when even poems are written in English, however, less and less often, and writing in Russian becomes a matter of past. His Russian Lolita's reception was univocally negative, harsh critics said it to be in an outdated, rusty language. Nabokov gave credit to these voices and abandoned similar projects forever. The comparison of the two Lolitas is a rewarding subject to study as a number of changes were done by the author himself that raises the theoretic question how to make a distinction between a self-translation and a version. J. Grayson writes about minor and major reworking analyzing in the second group three early self-translations of the 1930s (Laughter in the Dark, Despair, and King, Queen, Knave) because of eliminated chapters and episodes and change of names (GRAYSON 1977: 23-118). After years of investigations, I have arrived at a very simple conclusion: in a self-translated text, there are no changes of other kind that an outsider translator would permit to change. Omitting a chapter or an episode or inserting one is not of that kind, but changing names can be (telling names or names with a wordplay).

But Лолита needs a different category I propose to call auctorial translation. Here the structure, the plot and the main body of the text and of the idea were kept intact, and the playful text was changed because of the cultural differences of the languages, and mainly in order to follow the original style and allusions. With a few exceptions, a creative outsider translator could have allow to commit them. But translating Lolita into a third language raises two basic problems.

The first is a juridical and a philological one. Dmitry Nabokov contracted all translations of his father's works to be done from English as from later versions called by philology an ab ultima manu text, last touched by the author. In this case, the last versions of Lolita and The Enchanter (translated by Dmitry Nabokov after his father's death) are in Russian so they should have been translated from Russian.

The second problem is that there are two original texts in our hands, all two with their own merits. No publisher would risk to order two parallel translations, so the comparison of the two versions stays a subject for scholarly publications. In addition, two parallel publications in a third language would reflect two different translation strategies and personalities of the two translators. So, mathematical logic suggests entrust these two translations to the same translator - but my suggestion is to repair this imaginary split and merge not only the two translators into one but merge the two originals into one hybrid text. I can now posteriorly confess that

\footnotetext{
впадение между разноязычными начертаниями единозвучной буквы меняет и цветовое впечатление от нее (или, иначе говоря, каким именно образом сливаются в восприятии буквы ее звук, окраска и форма), может быть как-нибудь причастен понятию 'структурных' красок в природе. Любопытно, что большей частью русская, инакописная, но идентичная по звуку, буква отличается тускловатым тоном по сравнению с латинской” (НАБоков 1989: 28).
} 
I have translated two novels of Nabokov, Mary and Glory (actually, with minor changes in the self-translation), this way, without saying anything to the publisher. But this hybridizing method works also in more reworked texts, as I will try to demonstrate here. Hybridization seems to be an adequate concept for Nabokov's multilingual texts.

This proposition concerns only the method of the general approach. For example, even if the Russian Lolita is a later version, the American environment demands American English realia (a difficult task for the translator because of the playful and meaningful geographical names). But in many cases, especially when resolving the problem of cultural differences, Nabokov with his domesticating experience lends considerable assistance to his translators, first of all, when intertextual allusions emerge. He gives different clues: for the Russian reader he refers to Russian literature, while for the English one to English literature. The attention to both original texts might be revelative here: which one to choose by the translator into a third language?

In the famous first chapter of Lolita, we can read two reminiscences to Edgar Poe's poem Annabelle Lee, recognizable only for initiated readers: “...there might have been no Lolita at all had I not loved, one summer, a certain initial girl-child. In a princedom by the sea. [...] Ladies and gentlemen of the jury, exhibit number one is what the seraphs, the misinformed, simple, noble-winged seraphs, envied" (NAвокоv 1970: 11). These two references emphasized by me are only misquotations: in Poe's poem, we can read not princedom but kingdom and "winged seraphs of Heaven", and the translator (obliged to keep the reference's mistake, of course) wonders who commits the mistake, the author or his narrator. The answer is given in the Russian Lolita, where after the Russian version of Poe's poem it is added: "почти как у По" ('roughly as at Poe') that not only dispenses both the narrator and the author from the sin of being illiterate but also reveals the name of the poet hence transforming the reminiscence into an overt allusion affirmed even in a second remark to Poe's name: "seraphs of Edgar". Note that seraphs ring another bell for a Russian ear: six-winged seraphs are known from Pushkin's poem Пророк ("The Prophet"). This comparison (Nabokov's solution) almost entitles the thirdlanguage translator to specify by name and decode hidden intertextual references.

Another solution by Nabokov is when a cult reference in one culture is replaced by another, "domestic" one in the target-language culture or literature. At the end of Lolita in the grotesque dialog, Quilty makes a not very hidden reference to Shakespeare ("as the Bard said") before quoting the text with a spoiled pronunciation creating this way a wordplay: "to borrow > to-morrow". In his translation, Nabokov replaces "the Bard" by "the Poet", who might be only Pushkin for the Russians (“Буду жить долгами, как жил его отец, по словам поэта” - НАБоков 1991: 331). ${ }^{4}$ It must be noted that Nabokov could transfer any wordplay, the leered reference here was more important for him. A knotty question opens for the trans-

\footnotetext{
${ }^{4}$ These two lines are known of every schoolboy also by those who did not read even the first chapter of Eugene Onegin until its end.
} 
lator into a third language: which one to refer, Shakespeare or Pushkin, the Bard or the Poet? (No question to insert a quotation or reference from a third language here, of course.) In theory, it will depend on the particular language and culture, but not without pondering the quotation itself and its level of common knowledge. In Hungarian, reassured by the last example of Edgar Poe and the fact that Nabokov himself sacrificed the wordplay for demonstrating Quilty's playful erudition, I would decode the source and write "as the Poet says of Onegin's father".

Below, I would focus on some more examples where the hybridization of two original texts is of great help.

In wordplays, it is difficult to decide which aspect of the associations should be kept or replaced by the translator. Humbert H. argues that his both halves are feminine but "they were as different as mist and mast" (NABOKOv 1970: 20). An additional problem occurs with the quotation marks coming from the original, which, as I see, do not mark a quotation but the figurative sense. The phallic association with mast emerges due to the context, especially to the "viril ivory fascinum" (NABOKOv 1970: 20) and a stick, but mast can refer also to breast. The Russian original says "мечта и мачта", so the phallic connotation should be kept (this way humorously contradicting to HH's feminine halves he is speaking of).

The playfulness of the Russian and the later original version is sometimes on a higher level than the English one, as portmanteau words (a fusion of two words into one, hence easily reproducible) are doubled here. "Не сомневаюсь, что доктор Биянка Шварцман вознаградила бы меня целым мешком австрийских шиллингов, ежели бы я прибавил этот либидосон к ее либидосье" (НАБоков 1991: 69). Cf.: "I am sure Dr. Blanche Schwarzmann would have paid me a sack of schillings for adding such a libidream to her files" (NАвоKоv 1970: 56, italics added by Zs. H.). There is no doubt which version does more worth to translate.

Nabokov's texts existing in two authentic / authorial versions help to answer the theoretical question about the minimal and the maximal units of the translation. A Russian university textbook suggests that the word is the minimal unit and the given text is the maximal unit. ${ }^{5}$ As we could see, intertextual allusion and reminiscences lead the translation far beyond the limits of a given text. On the other hand, the minimal unit can also be a morpheme or even a letter if semanticized. As I proposed earlier, in Nabokov's texts, every letter can bear a meaning because they are interpreted as mini-images evoking synaesthetic associations in Nabokov's mind by their graphic form (HETÉNYi 2011, ХЕтени 2015).

Nabokov's self-references charge the translator a difficult task of being initiated into the whole oeuvre of the writer. An easy reference is when only characters from earlier texts reappear in a new text, as Alfyorovs walking in for a short conversation in a park with Luzhins (The Defense, 1930). The good reader is informed only here that Mary, Alfyorov's wife really did arrive in Berlin but already beyond the last word of the novel Mary (Машенька, 1926).

5 “...слово как минимальная единица и текст как максимальная единица перевода...” (Солодуь и др. 2005). The whole book is split in two halves according these two units. 
More sophisticated are the meetings of not men but words inside the oeuvre composing webs of invariant patterns, hypermotifs and leitmotifs. I apply the term invariant (first used for Nabokov in a different meaning by Yuri Levin, see Левин 1998) for designating words bearing metaphoric, iconic, or symbolic connotations and reappear in different texts where they gradually develop into motifs. They often absorb several connotations because of their possible readings with different decoding systems (literary and cultural allusions such as mythology and the Bible, or even chess and zoology for Nabokov) and become polygenetic (many-rooted). One of them is the poplar (тополь) put into the text always, as I argue, with a connotation of death or otherworld, which meaning can be derived from the Fields of Elysium depicted by Homer. I dare to say they are "put into the text" because Nabokov let understand that conscious gesture by his own meta-literary remark from his early short story Leonardo (1933), where poplars make part of the yard scenery ordered and hastened to carry in by the narrator. In the Russian Lolita, we also get an evidence of their figurative meaning: "The implied sun pulsated in the supplied poplars...". ${ }^{6}$ Poplars have different subspecies in Central Europe and some of them are designated by various words coming from different regions of the language (e.g. jegenye, topolya, nyárfa in Hungarian). For maintaining the thread of the invariant motif (see HETÉNYI 2008), it is highly recommended to use one and the same word for all 20 books of Nabokov and this word should, according to my theory, have at least one meaningful letter "o" in it (for "o", see HeTÉNYI 2011).

For this short article, I have several conclusions about the translation of selftranslating authors with two original texts in different languages.

The best practice is to translate from two originals and make a hybrid text. The hybrid text means to choose the more poeticized one at different places in the text. Nabokov offers a solution for translators to decode intertextual allusions by inserting explicit information (names and titles). His domestication strategy can be applied very rarely by a translator. Translation concerns every semanticized minute unit of the text and it embraces all texts of humankind.

\section{References}

GraYson 1977 = GraYson J. Nabokov Translated. A Comparison of Nabokov's Russian and English Prose. Oxford University Press, 1977.

HeTÉNYI 2008 = HetÉNYI Zsuzsa: Lolita as Goddess Between Life and Death: from Persephone to the Poplars. Mythical Allusions in Nabokov's Novel. Intertexts. A Journal of Comparative and Theoretical Reflection 12 (2008): 41-54.

HETÉNYI 2011 = HETÉNYI Zsuzsa: Lionized in Berlin. Translating „A Guide to Berlin” by Vladimir Nabokov. In: Ritka müvészet. Írások Péter Ágnes tiszteletére / Rare Device. Writings in Honour of Ágnes Péter. Budapest: ELTE BTK, 2011. 325-340.

HETÉNYI 2018 = HETÉNYI Zsuzsa: The Carroll Carroll Pattern. Nabokov and Lewis Carroll. Toronto Slavic Quarterly 63 (2018): 1-19.

6 “Подразумеваемое солнце пульсировало в подставных тополях" (НАБоков 1991: 75). 
Naвокоv $1970=$ NaвоKov V. The Annotated Lolita . Edited by A. Appel Jr. New York: McGraw-Hill, 1970.

NABOKOV 1997 = NABOKOV V. Stories. New York: Vintage Books, 1997.

NaвоKov 2000 = NaвоKov V. Speak, Memory! An Autobiography Revisited. Penguin Books Classics, 2000.

NABOKov 2011 = NABOKov V. Pale Fire. Penguin Books Classics, 2011.

ЛЕВин 1998 = ЛЕВин Ю. И. Биспациальность как инвариант поэтического мира Набокова. В кн.: ЛЕвин Ю. И. Избранные труды. Поэтика. Семиотика. Москва: «Языки русской культуры», 1998. 323-392.

НАБоков 1923 = НАБОКОВ В. Аня в стране чудес. Берлин: «Гамаюн», 1923.

НАБоков 1989 = НАБоков В. Другие берега. Москва: «Книжная палата», 1989.

НАБоков 1991 = НАБоков В. Лолита. Москва: «Художественная литература», 1991.

СолОдУБ и др. 2005 = СоЛОДУБ Ю. П., АЛЬБРЕХТ Ф. Б., КУзНЕцОВ А. Ю. Теория и практика художественного перевода. Москва: «Асаdemia», 2005.

ХЕТЕНИ 2015 = ХЕТЕНИ Ж. Взор и узоры прозы - два типа интерпретации в семантизации букв и клеточные анаграммы. Набоков и предшественники. В кн.: ЖАКкАР Ж.-Ф., МорАР А. (сост.) 1913 - «Слово как таковое». К юбилейному году русского футуризма. Санкт-Петербург: Издательство Европейского университета, 2015. 446-460. 